\title{
VIRULENCE OF PYRENOPHORA TRITICI-REPENTIS: A MINIREVIEW
}

\author{
*Jānis Kaṇeps ${ }^{1}$, Biruta Bankina ${ }^{1}$, Inga Moročko-Bičevska ${ }^{1,2}$ \\ ${ }^{1}$ Latvia University of Life Sciences and Technologies, Latvia \\ ${ }^{2}$ Institute of Horticulture, Latvia \\ *Corresponding author’s email: Janis.Kaneps@llu.lv
}

\begin{abstract}
Pyrenophora tritici-repentis is a major wheat pathogen in all wheat (Triticum spp.) growing areas worldwide. Up to date, eight $P$. tritici-repentis races have been described based on chlorosis, necrosis, or both symptoms caused on race differential wheat genotypes: 'Glenlea', 6B662, 6B365, and 'Salamouni'. Symptom development on differential genotypes depends on the interaction of the pathogen's necrotrophic effectors named Ptr ToxA, Ptr ToxB, and Ptr ToxC with host susceptibility genes. Ptr ToxA is encoded by the single copy gene Tox $A$ and induces necrosis on sensitive wheat cultivars. Ptr ToxB causes chlorosis and is encoded by the multicopy gene ToxB. The Ptr ToxC is the non-proteinaceous, polar, low molecular mass molecule that also induces chlorosis, but up to date, the gene encoding this toxin is unknown. Races producing Ptr ToxA are predominant in the global Ptr population. There are several reports about new putative races of $P$. tritici-repentis that do not conform with the current race system, so further research is required. This study aims to collect and systematise available information about the virulence and races of P. tritici-repentis.
\end{abstract}

Key words: races, necrotrophic effectors, population, tan spot, wheat.

\section{Introduction}

Tan spot caused by Pyrenophora tritici-repentis (Ptr), from the phylum Ascomycota order Pleosporales is a notable wheat foliar disease in all major wheat (Triticum spp.) growing regions (Ciuffetti et al., 2014; Strelkov \& Lamari, 2003). It is one of the most devastating wheat diseases in Latvia and Lithuania (Ronis et al., 2009; Švarta et al., 2020).

Besides wheat, triticale ( $\times$ Triticosecale), rye (Secale cereale), barley (Hordeum vulgare), also various grasses from Poaceae family are known as host plants of Ptr (Ali \& Francl, 2003; Hosford, 1971; Krupinsky, 1982; Misra, Pandey, \& Misra, 1979).

The first who described and isolated the asexual stage of this pathogen from Elymus repens was Diedicke in Germany in 1902 (Diedicke, 1902). Diedicke classified the newly found fungus as Helminthosporium graminearum Rab. ex Schlecht. f. sp. tritici-repentis Died., with Pleospora trichostoma (Fr.) Fuckel. as its teleomorph. In 1903, Diedicke renamed this species as Helminthosporium triticirepentis Died. and Pleospora tritici-repentis Died. Later, in 1923, Drechsler classified it as Pyrenophora tritici-repentis (Died.) Drechs. based on setae presence on the fruiting body (pseudothecia). In 1928, the fungus asexual stage was isolated from wheat and identified as Helminthosporium tritici-vulgaris (Nisikado) by Nisikado. In 1930, Ito, based on conidia germination peculiarities, renamed $H$. triticivulgaris as Drechslera tritici-vulgaris (Hosford, 1981; Maraite, 1997). All synonyms for both morphs were revised by Shoemaker (1962) as Pyrenophora tritici-repentis (Died.) Drechs. for sexual state and Drecshlera tritici-repentis (Died.) Shoem. for the asexual state (Hosford, 1981; Maraite, 1997). In 2014, the scientific community supported using the genus name Pyrenophora over Drechslera, thus adopting Pyrenophora tritici-repentis (Died.) Drechs. as a sole name (holomorph) of the pathogen (Wijayawardene et al., 2014).

Up to date 8 different $P$ tr races have been described, based on necrotrophic effectors (NEs) they produce and symptoms they cause on defined host-plant differential set (Lamari et al., 2003). These NEs are called Ptr ToxA, Ptr ToxB, and Ptr ToxC and can cause two different symptoms on the host plants - necrosis and/or chlorosis (Lamari \& Bernier, 1989).

The diversity of the pathogen's population is related to different aspects of disease development and control possibilities, such as overcoming cultivar resistance and sensitivity to fungicides. This study aims to collect and organise available information about Ptr populations to understand wheat-pathogen interactions better and gain knowledge for the adaptation of plant protection strategy.

\section{Materials and Methods}

In the present study a monographic approach was used. The results of worldwide research on the taxonomy, biology and population diversity focusing on the virulence of Ptr were summarised and analysed.

\section{Results and Discussion}

Races of P. tritici-repentis

Ptr can cause two different types of symptoms necrosis and chlorosis. Lamari and Bernier (1989) proposed to group Ptr isolates into four pathotypes based on the expressed symptoms on a set of racedifferential wheat genotypes. Initially, isolates belonging to pathotype 1 were thought to cause either extensive necrosis or extensive chlorosis $\left(\mathrm{nec}^{+} \mathrm{chl}^{+}\right)$, 
until Lamari, Bernier and Smith (1991) reported that wheat genotypes are able to express both necrosis and chlorosis simultaneously. Isolates that induced only necrosis were grouped into pathotype $2\left(\mathrm{nec}^{+}\right.$ $\mathrm{chl}^{-}$), while isolates that caused only chlorosis were considered pathotype $3\left(\mathrm{nec}^{-} \mathrm{chl}^{+}\right)$. Avirulent isolates were classified as pathotype 4 (nec $\left.\mathrm{chl}^{-}\right)$.

Sorting Ptr isolates into four pathotypes proved insufficient as Lamari et al. (1995) found chlorosis $\left(\mathrm{nec}^{-} \mathrm{chl}^{+}\right)$inducing isolates from Algeria, which had a different virulence pattern from previously described pathotype 3 . These isolates were virulent on the wheat cultivar 'Katepwa' and avirulent on the line 6B365, which was directly opposite to pathotype 3, which caused chlorosis on 6B635 and was avirulent on 'Katepwa'. Therefore, Lamari et al. (1995) proposed to use race designation to specify Ptr virulence (Table 1). Races 1, 2, 3 and 4 represent the formerly described four pathotypes; the newly characterised isolates were assigned as race 5 . Race 6 combines the virulence patterns of races 3 and 5, as it causes extensive chlorosis on both 'Katepwa' and 6B635. Likewise, race 5 induces chlorosis on wheat line 6B662 that is resistant to the first four races (Strelkov et al., 2002). Race 7 causes necrosis on 'Glenlea' and chlorosis on 6B662, combining the virulence patterns of races 2 and 5. Race 8 induces necrosis on 'Glenlea', and chlorosis on $6 \mathrm{~B} 662$ and 6B365, combining the virulence of races 2, 5, and 3 (Lamari et al., 2003; Lamari et al., 2005).

\section{Virulence factors of P. tritici-repentis}

Necrotrophic effectors determine virulence factors of the known Ptr races (NEs), historically called hostselective toxins (HSTs) (Ciuffetti et al., 2010; Tomas $\&$ Bockus, 1987). The set of race differential wheat genotypes defined by Lamari et al. (2003) is based on the symptoms expressed by these genotypes in response to the infection by a specific race of the pathogen (Table 1). Previous research (Ballance, Lamari, \& Bernier, 1989; Effertz et al., 2002; Orolaza, Lamari, \& Ballance, 1995) revealed that these reactions follow an inverse-gene-for-gene model, as wheat sensitivity to the specific NEs produced by Ptr is determined by compatibility between NEs and host susceptibility genes, while insensitivity is observed if the host and NEs are incompatible (Lamari et al., 2003). Ciuffetti et al. (1998) published a standardised nomenclature for Ptr virulence factors and genes involved to resolve problems arising from the multiple names for the same necrotrophic effector and the regulating gene. NEs are named as Ptr ToxA, Ptr ToxB, and Ptr ToxC in the order of their characterisation. The genes are named according to the NEs and encode ToxA, ToxB, ToxC, respectively (Ciuffetti et al., 2014).

Ptr ToxA produced by races 1, 2, 7 and 8 induces necrosis on susceptible wheat cultivars (Lamari \& Bernier, 1989; Lamari et al., 2003). Ptr ToxA is a protein that is synthesized ribosomally and is encoded by a single ToxA gene. ToxA encodes a 23 amino acid signal peptide, a 38 amino acid $(4.3 \mathrm{kDa})$ pro-domain

Table 1

The reaction of differential wheat genotypes to the known races of Pyrenophora tritici-repentis

\begin{tabular}{|c|c|c|c|c|c|c|c|c|c|}
\hline \multirow{2}{*}{$\begin{array}{l}\operatorname{Race}^{\mathrm{a}} \text { (ToxA, } \\
\text { ToxB, ToxC) }\end{array}$} & \multirow{2}{*}{ Reported by } & \multicolumn{5}{|c|}{ Hexaploid genotypes } & \multicolumn{3}{|c|}{ Tetraploid genotypes } \\
\hline & & Glenlea & $6 \mathrm{~B} 662$ & $6 \mathrm{~B} 365$ & Katepwa & Salamouni & ND495 & Coulter & 4B1169 \\
\hline $1(+,-,+)$ & \multirow{4}{*}{$\begin{array}{c}\text { (Lamari \& } \\
\text { Bernier, 1989) } \\
\text { (Ali \& Francl, } \\
\text { 2002) }\end{array}$} & $\mathrm{S}(\mathrm{N})^{\mathrm{b}}$ & $\mathrm{R}$ & $\mathrm{S}(\mathrm{C})$ & $\mathrm{S}(\mathrm{N})$ & $\mathrm{R}$ & $\mathrm{S}(\mathrm{N})$ & $\mathrm{S}(\mathrm{N})$ & $\mathrm{R}$ \\
\hline $2(+,-,-)$ & & $\mathrm{S}(\mathrm{N})$ & $\mathrm{R}$ & $\mathrm{R}$ & $\mathrm{S}(\mathrm{N})$ & $\mathrm{R}$ & $\mathrm{S}(\mathrm{N})$ & $\mathrm{S}(\mathrm{N})$ & $\mathrm{R}$ \\
\hline $3(-,-,+)$ & & $\mathrm{R}$ & $\mathrm{R}$ & $\mathrm{S}(\mathrm{C})$ & $\mathrm{R}$ & $\mathrm{R}$ & $\mathrm{R}$ & $\mathrm{S}(\mathrm{N})$ & $\mathrm{R}$ \\
\hline $4(-,-,-)$ & & $\mathrm{R}$ & $\mathrm{R}$ & $\mathrm{R}$ & $\mathrm{R}$ & $\mathrm{R}$ & $\mathrm{R}$ & $\mathrm{R}$ & $\mathrm{R}$ \\
\hline $5(-,+,-)$ & $\begin{array}{c}\text { (Lamari et al., } \\
1995) \\
\text { (Ali \& Francl, } \\
\text { 2002) }\end{array}$ & $\mathrm{R}$ & $\mathrm{S}(\mathrm{C})$ & $\mathrm{R}$ & $\mathrm{S}(\mathrm{C})$ & $\mathrm{R}$ & $\mathrm{R}$ & $\mathrm{S}(\mathrm{N})$ & $\mathrm{R}$ \\
\hline $6(-,+,+)$ & $\begin{array}{c}\text { (Strelkov et al., } \\
\text { 2002) } \\
\text { (Ali \& Francl, } \\
\text { 2002) }\end{array}$ & $\mathrm{R}$ & $\mathrm{S}(\mathrm{C})$ & $\mathrm{S}(\mathrm{C})$ & $\mathrm{S}(\mathrm{C})$ & $\mathrm{R}$ & - & $\mathrm{S}(\mathrm{N})$ & $\mathrm{R}$ \\
\hline $7(+,+,-)$ & \multirow{2}{*}{$\begin{array}{l}\text { (Lamari et al., } \\
\text { 2003) } \\
\text { (Ali \& Francl, } \\
\text { 2002) }\end{array}$} & $\mathrm{S}(\mathrm{N})$ & $\mathrm{S}(\mathrm{C})$ & $\mathrm{R}$ & $\mathrm{S}(\mathrm{N})$ & $\mathrm{R}$ & $\mathrm{S}(\mathrm{N} / \mathrm{C})$ & $\mathrm{S}(\mathrm{N})$ & $\mathrm{R}$ \\
\hline $8(+,+,+)$ & & $\mathrm{S}(\mathrm{N})$ & $\mathrm{S}(\mathrm{C})$ & $\mathrm{S}(\mathrm{C})$ & $\mathrm{S}(\mathrm{N})$ & $\mathrm{R}$ & $\mathrm{S}(\mathrm{N})$ & $\mathrm{S}(\mathrm{N})$ & $\mathrm{R}$ \\
\hline
\end{tabular}

${ }^{a}$ Races are characterised by their production of three NEs - Ptr ToxA, Ptr ToxB, and Ptr ToxC.

${ }^{\mathrm{b}} \mathrm{S}$ - susceptible; $\mathrm{R}$ - resistant; (N) - necrosis; (C) - chlorosis; (N/C) - necrosis and chlorosis; - - symptoms are unknown. 
Table 2

Geographic distribution of $P$. tritici-repentis races and their proportion $(\%)$ in analysed populations

\begin{tabular}{|l|c|c|c|c|c|c|c|c|}
\hline \multirow{3}{*}{ Country } & \multicolumn{9}{|c|}{ Race, proportion (\%) } \\
\cline { 2 - 10 } & 1 & 2 & 3 & 4 & 5 & 6 & 7 & 8 \\
\hline USA & $40-84$ & $1-4$ & 32 & $13-32$ & 1 & 0 & 0 & 0 \\
\hline Canada & $62-90$ & $36-50$ & 2 & 0 & 0 & 0 & 0 & 0 \\
\hline Argentina & 2 & 6 & 1.5 & 22 & 2 & 2 & 0 & 20 \\
\hline Brazil & 35 & 65 & 0 & 0 & 0 & 0 & 0 & 0 \\
\hline Algeria & 41 & 0 & 0 & 2 & 5 & 4 & 40 & 2 \\
\hline Morocco & 6 & 0 & 0 & 0 & 47 & 44 & 2 & 0 \\
\hline Tunisia & 0 & 1 & 0 & 1 & 4 & 0 & 49 & 0 \\
\hline Iran & 90 & 10 & 0 & 0 & 0 & 0 & 0 & 0 \\
\hline Kazakhstan & $46-95$ & $5-35$ & $0-23$ & 0 & 0 & 0 & 0 & $0-34$ \\
\hline Azerbaijan & 64 & 3 & 1 & 0 & 13 & 0 & 8 & 11 \\
\hline Kyrgyzstan & 100 & 0 & 0 & 0 & 0 & 0 & 0 & 0 \\
\hline Uzbekistan & 100 & 0 & 0 & 0 & 0 & 0 & 0 & 0 \\
\hline Syria & 8 & 0 & 58 & 0 & 8 & 0 & 17 & 8 \\
\hline Russia & $13-23$ & $0-45$ & $0-33$ & $5-61$ & 0 & 0 & $0-5$ & $5-13$ \\
\hline Finland & 19 & 19 & 4 & 10 & 0 & 10 & 0 & 38 \\
\hline Romania & 80 & 16 & 2 & 0 & 0 & 0 & 0 & 0 \\
\hline Lithuania & 48 & 1 & 20 & 5 & 0 & 0 & 0 & 0 \\
\hline Latvia & 90 & 10 & 0 & 0 & 0 & 0 & 0 & 0 \\
\hline
\end{tabular}

peptide responsible for proper protein folding. Both regions are cut off before synthesizing the final 13.2 kDa (118 amino acid) Ptr ToxA protein (Balance et al., 1996; Ciuffetti et al., 2010; Tomas et al., 1990; Tuori, Wolpert, \& Ciuffetti, 1995). Ptr ToxA activity is determined by solvent-exposed loops containing arginyl-glycyl-aspartic acid (RGD) (Sarma et al., 2005). Manning et al. (2008) reported that a RGD loop is necessary for Ptr ToxA activity, receptor recognition and internalization. The internalization mechanism of Ptr ToxA is unknown. One of the hypotheses is that Ptr ToxA is uptaken via receptor-mediated endocytosis (Ciuffetti et al., 2014). Chloroplasts are the localization targets of internalized Ptr ToxA, and cell death induced by Ptr ToxA is light-dependent. Ptr ToxA causes the accumulation of reactive oxygen species (ROS), which correlates with the induction of necrosis symptoms. Necrosis is prevented by inhibiting ROS accumulation (Manning et al., 2009; Manning \& Ciuffetti, 2005).

Races 5, 6, 7 and 8 produce Ptr ToxB (Lamari et al., 2003; Strelkov et al., 2002). Orolaza, Lamari, and Ballance (1995) were the first who identified Ptr ToxB in culture filtrates of Ptr. Ptr ToxB is a small protein of $6.6 \mathrm{kDa}$ mass known to induce chlorosis on sensitive wheat cultivars by a mechanism that affects chlorophyll photooxidation (Strelkov, Lamari, \& Ballance, 1998; 1999). Depending on each race and isolate Ptr ToxB coding, ToxB is found in multiple copies varying from 2 to 10 copies (Lamari et al., 2003; Martinez, Oesch, \& Ciuffetti, 2004). Copy number of ToxB correlates with Ptr ToxB expression level and isolate virulence (Amaike et al., 2008; Strelkov et al., 2002; 2006). Ptr race 4 has a single copy of the gene toxb that is $86 \%$ similar to ToxB gene and codes a protein that is $81 \%$ similar to $\operatorname{Ptr}$ ToxB (Martinez, Oesch, \& Ciuffetti, 2004) and is avirulent in Ptr ToxB sensitive wheat genotypes (Figueroa Betts et al., 2011). There is evidence that besides chlorosis induction, Ptr ToxB has additional functions connected to basic pathogenic abilities (Aboukhaddour, Kim, \& Strelkov, 2012; Amaike et al., 2008).

Ptr ToxC is produced by races 1, 3, 6 and 8 (Gamba, Lamari, \& Brülé-Babel, 1998; Lamari et al., 2003; Strelkov et al., 2002). Ptr ToxC is a nonproteinaceous, low molecular mass, non-ionic, polar molecule (Effertz et al., 2002). Like Ptr ToxB, it can cause chlorosis on susceptible hexaploid wheat genotypes while causing necrosis on susceptible tetraploid wheat lines (Lamari et al., 1995). To date, there are no data about which gene encodes Ptr ToxC production.

Geographic distribution of $P$. tritici-repentis races

The population of Ptr is plastic and adapts to various climatic and agroecological conditions. Studies show that the Ptr population varies depending on the geographic location and host diversity (Table 
The reaction of differential wheat genotypes to the potentially new $P$. tritici-repentis races

\begin{tabular}{|c|c|c|c|c|c|c|c|c|c|}
\hline \multirow{2}{*}{$\begin{array}{r}\text { Strain (ToxA, } \\
\text { ToxB, ToxC) }\end{array}$} & \multirow{2}{*}{ Reported by } & \multicolumn{5}{|c|}{ Hexaploid genotypes } & \multicolumn{3}{|c|}{ Tetraploid genotypes } \\
\hline & & Glenlea & $6 \mathrm{~B} 662$ & $6 \mathrm{~B} 365$ & Katepwa & Salamouni & ND495 & Coulter & 4B1169 \\
\hline $\mathrm{nc1}(-,-,-)^{\mathrm{a}}$ & (Ali et al., 2002) & $\mathrm{S}(\mathrm{N})^{\mathrm{b}}$ & $x$ & $\mathrm{~S}(\mathrm{~N})$ & $\mathrm{S}(\mathrm{N})$ & $\mathrm{S}(\mathrm{N})$ & $\mathrm{S}(\mathrm{N})$ & $x$ & $x$ \\
\hline $\mathrm{SO} 3(-,-,-)$ & \multirow{2}{*}{$\begin{array}{c}\text { (Andrie, } \\
\text { Pandelova, \& } \\
\text { Ciuffetti, 2007) }\end{array}$} & $\mathrm{S}(\mathrm{N})$ & $\mathrm{R}$ & $\mathrm{R}$ & $\mathrm{S}(\mathrm{N})$ & $\mathrm{R}$ & $x$ & $x$ & $x$ \\
\hline PT82(+,-,+) & & $\mathrm{S}(\mathrm{N})$ & $\mathrm{S}(\mathrm{C})$ & $\mathrm{S}(\mathrm{C})$ & $\mathrm{S}(\mathrm{C})$ & $\mathrm{R}$ & $x$ & $x$ & $x$ \\
\hline $\begin{array}{c}\text { AR CrossA5 } \\
(-,-,+)\end{array}$ & \multirow{2}{*}{$\begin{array}{l}\text { (Ali, Gurung, \& } \\
\text { Adhikari, 2010) }\end{array}$} & $\mathrm{S}(\mathrm{N})$ & $\mathrm{R}$ & $\mathrm{S}(\mathrm{C})$ & $x$ & $\mathrm{R}$ & $x$ & $x$ & $x$ \\
\hline $\begin{array}{c}\text { AR LonB2 } \\
(-,-,+)\end{array}$ & & $\mathrm{R}$ & $\mathrm{R}$ & $\mathrm{S}(\mathrm{C})$ & $\mathrm{S}(\mathrm{C})$ & $\mathrm{R}$ & $x$ & $x$ & $x$ \\
\hline $\operatorname{Ptr} 24(-,-,-)$ & $\begin{array}{l}\text { (Benslimane } e t \\
\text { al., 2011) }\end{array}$ & $\mathrm{R}$ & $\mathrm{R}$ & $\mathrm{R}$ & $x$ & $\mathrm{R}$ & $x$ & $\mathrm{~S}(\mathrm{~N})$ & $\mathrm{R}$ \\
\hline $\mathrm{A} 029(+,-,-)$ & \multirow{18}{*}{$\begin{array}{c}\text { (Moreno, } \\
\text { Stenglein, \& } \\
\text { Perelló, 2015) }\end{array}$} & $\mathrm{S}(\mathrm{N} / \mathrm{C})$ & $\mathrm{R}$ & $\mathrm{R}$ & $\mathrm{R}$ & $\mathrm{R}$ & $\times$ & $\times$ & $\times$ \\
\hline B028(+,-,-) & & $\mathrm{R}$ & $\mathrm{R}$ & $\mathrm{R}$ & $\mathrm{R}$ & $\mathrm{R}$ & $x$ & $x$ & $x$ \\
\hline $\mathrm{CH} 007(+,-,-)$ & & $\mathrm{S}(\mathrm{C})$ & $\mathrm{R}$ & $\mathrm{R}$ & $\mathrm{S}(\mathrm{N})$ & $\mathrm{R}$ & $\times$ & $\times$ & $\times$ \\
\hline CH009 $(-,-,-)$ & & $\mathrm{R}$ & $\mathrm{R}$ & $\mathrm{R}$ & $\mathrm{R}$ & $\mathrm{S}(\mathrm{N})$ & $\times$ & $x$ & $x$ \\
\hline $\mathrm{CP} 021(+,-,-)$ & & $\mathrm{S}(\mathrm{N} / \mathrm{C})$ & $\mathrm{R}$ & $\mathrm{R}$ & $\mathrm{S}(\mathrm{N})$ & $\mathrm{R}$ & $\times$ & $\times$ & $\times$ \\
\hline CR0819(+,-,+) & & $\mathrm{R}$ & $\mathrm{R}$ & $\mathrm{S}(\mathrm{C})$ & $\mathrm{R}$ & $\mathrm{R}$ & $\times$ & $x$ & $x$ \\
\hline G032(-,-,-) & & $\mathrm{S}(\mathrm{N})$ & $\mathrm{R}$ & $\mathrm{R}$ & $\mathrm{R}$ & $\mathrm{R}$ & $x$ & $x$ & $x$ \\
\hline $\mathrm{G} 0316(+,-,+)$ & & $\mathrm{S}(\mathrm{N})$ & $\mathrm{R}$ & $\mathrm{S}(\mathrm{C})$ & $\mathrm{R}$ & $\mathrm{R}$ & $x$ & $x$ & $x$ \\
\hline G0321(-,-,+) & & $\mathrm{R}$ & $\mathrm{R}$ & $\mathrm{S}(\mathrm{C})$ & $\mathrm{R}$ & $\mathrm{S}(\mathrm{C})$ & $x$ & $x$ & $x$ \\
\hline $\mathrm{G} 0328(+,-,+)$ & & $\mathrm{S}(\mathrm{N})$ & $\mathrm{S}(\mathrm{C})$ & $\mathrm{S}(\mathrm{C})$ & $\mathrm{R}$ & $\mathrm{R}$ & $x$ & $x$ & $x$ \\
\hline $\mathrm{G} 0333(+,-,-)$ & & $\mathrm{R}$ & $\mathrm{R}$ & $\mathrm{R}$ & $\mathrm{S}(\mathrm{N})$ & $\mathrm{R}$ & $\times$ & $x$ & $\times$ \\
\hline $\mathrm{H} 001(+,-,-)$ & & $\mathrm{S}(\mathrm{N})$ & $\mathrm{S}(\mathrm{C})$ & $\mathrm{S}(\mathrm{C})$ & $\mathrm{S}(\mathrm{N} / \mathrm{C})$ & $\mathrm{S}(\mathrm{N})$ & $x$ & $x$ & $x$ \\
\hline $\mathrm{H} 0014(+,-,-)$ & & $\mathrm{S}(\mathrm{C})$ & $\mathrm{R}$ & $\mathrm{S}(\mathrm{C})$ & $\mathrm{R}$ & $\mathrm{R}$ & $x$ & $x$ & $x$ \\
\hline $\mathrm{H} 016(+,-,-)$ & & $\mathrm{S}(\mathrm{N})$ & $\mathrm{S}(\mathrm{C})$ & $\mathrm{S}(\mathrm{C})$ & $\mathrm{R}$ & $\mathrm{S}(\mathrm{C})$ & $\times$ & $x$ & $x$ \\
\hline $25 \mathrm{M} 031(+,-,-)$ & & $\mathrm{R}$ & $\mathrm{R}$ & $\mathrm{R}$ & $\mathrm{S}(\mathrm{N} / \mathrm{C})$ & $\mathrm{R}$ & $\times$ & $\times$ & $\times$ \\
\hline $25 \mathrm{M} 036(+,-,-)$ & & $\mathrm{R}$ & $\mathrm{R}$ & $\mathrm{S}(\mathrm{C})$ & $\mathrm{S}(\mathrm{N})$ & $\mathrm{R}$ & $\times$ & $\times$ & $\times$ \\
\hline O0019(+,-,-) & & $\mathrm{S}(\mathrm{N})$ & $\mathrm{S}(\mathrm{C})$ & $\mathrm{R}$ & $\mathrm{S}(\mathrm{N} / \mathrm{C})$ & $\mathrm{S}(\mathrm{C})$ & $\times$ & $\times$ & $x$ \\
\hline $\mathrm{P} 028(+,-,-)$ & & $\mathrm{S}(\mathrm{N} / \mathrm{C})$ & $\mathrm{S}(\mathrm{C})$ & $\mathrm{S}(\mathrm{C})$ & $\mathrm{R}$ & $\mathrm{R}$ & $\times$ & $\times$ & $\times$ \\
\hline $\mathrm{nc} 2(-,-,+)$ & \multirow{2}{*}{$\begin{array}{c}\text { (Abdullah et al., } \\
\text { 2017) }\end{array}$} & $\mathrm{S}(\mathrm{N})$ & $\mathrm{R}$ & $\mathrm{S}(\mathrm{C})$ & $x$ & $\mathrm{R}$ & $x$ & $x$ & $x$ \\
\hline $\mathrm{nc} 3(-,-,-)$ & & $\mathrm{S}(\mathrm{N})$ & $\mathrm{R}$ & $\mathrm{R}$ & $x$ & $\mathrm{R}$ & $x$ & $x$ & $x$ \\
\hline B16 (-,-,-) & $\begin{array}{c}\text { (Guo, Shi, \& } \\
\text { Liu, 2018) }\end{array}$ & $\mathrm{S}(\mathrm{N})$ & $\mathrm{R}$ & $\mathrm{R}$ & $x$ & $\mathrm{R}$ & $\mathrm{S}(\mathrm{N})$ & $x$ & $x$ \\
\hline $\mathrm{T} 128-1(-,+,-)$ & $\begin{array}{c}\text { (Kamel et al., } \\
\text { 2019) }\end{array}$ & $\mathrm{S}(\mathrm{N})$ & $\mathrm{S}(\mathrm{C})$ & $\mathrm{R}$ & $x$ & $\mathrm{R}$ & $x$ & $x$ & $x$ \\
\hline
\end{tabular}

${ }^{a}$ if the name of the strain is not stated in the publication, then the code nc (not conform) is assigned.

${ }^{\mathrm{b}} \mathrm{S}$ - susceptible; R - resistant; (N) - necrosis; (C) - chlorosis; (N/C) - necrosis and chlorosis; $\times$ - symptoms were not investigated;

2). In Canada, races 1 and 2 are predominant in the local Ptr population (Aboukhaddour, Turkington, \& Strelkov, 2013).
In Argentina, Moreno, Stenglein and Perelló (2015) it was reported that only $54 \%$ could be assigned to the eight known races, with races 4 and 8 being the 
most widespread. Ptr race 2 is predominant in Brazil (Bertagnolli et al., 2019). These findings contradict the earlier report by Ali and Francl (2002), which indicated that race 1 is the most dominant Ptr race in South America.

Races 1 and 7 formed most of the Algerian Ptr population, while races 4,5 and 6 were rarely observed. (Benslimane et al., 2011). The situation is similar in Tunisia, where, according to Kamel et al. (2019), race 7 is predominant, and races 2, 4 and 5 are in the minority. In Morocco, races 5 and 6 are the most typical representatives of the population (Gamba, Bassi, \& Finckh, 2017).

The Ptr population in Iran is dominated by race 1 (Momeni et al., 2014). Race 1 also is predominant in Kazakhstan, and in some sites, race 8 was found the second most widespread Ptr race (Молдажанова, Мауленбай, \& Рсалиев, 2020). Lamari et al. (2005) analysed Ptr race diversity near the centre of wheat origin - the Fertile Crescent and the Caucasus - and found that the most diverse Ptr populations are in Syria and Azerbaijan.

Race 4 is predominant in southern Russia, and race 1 is the most widespread in northern Russia. Races 1, 2, 3 and 4 are commonly seen in the western part of Russia, with no race being distinctively predominant. The Ptr population of Finland is dominated by race 8 (Мироненко, Коваленко, \& Баранова, 2019).

In Europe and the Baltic states, the diversity of the Ptr population is insufficiently studied. Abdullah et al. (2017) reported that in Lithuania and Latvia, the most common race is race 1 . They also observed that in Romania, similarly to the Baltic states, race 1 is predominant. More detailed research is necessary. Indications of new $P$. tritici-repentis races and their geographic distribution
Some researchers have reported about possible new Ptr races with different virulence patterns (Table 3). Ali et al. (2002) reported a putative necrotrophic effector that caused extensive chlorosis on the tetraploid wheat line ND495, which is insensitive to Ptr ToxC. This NE was similar in size to Ptr ToxC, but had distinct chemical properties. Pandelova and Ciuffetti (2005) identified a proteinaceous toxin in the Ptr strains lacking ToxA gene that induced the same symptoms on the wheat differential set as Ptr ToxA. The current race system can describe only eight races, so discovering the new NEs like Ptr ToxD, Ptr ToxE, etc., and/or new differentials is necessary to incorporate new races in the existing model (Lamari \& Strelkov, 2010).

\section{Conclusions}

1. Races capable of producing Ptr ToxA are predominant in the global Ptr population, and possibly this is the result of the selective pressure from cultivars used in modern agriculture.

2. Various researchers worldwide have reported new Ptr races, but further research is needed as the key elements necessary for the description of these races have not yet been found.

3. There are many regions where the diversity of the Ptr population is not sufficiently investigated, and these knowledge gaps should be filled to gain a better understanding of the global Ptr population and wheat-pathogen interaction mechanisms.

\section{Acknowledgments}

The research was supported by the project "Features of tan spot (caused by Pyrenophora triticirepentis), development and control possibilities in Republic of Latvia and Republic of Belarus, 2020 2021."

\section{References}

Abdullah, S., Sehgal, S.K., Ali, S., Liatukas, Z., Ittu, M., \& Kaur, N. (2017). Characterization of Pyrenophora tritici-repentis (Tan Spot of Wheat) Races in Baltic States and Romania. The Plant Pathology Journal, 33(2), 133-139. DOI: 10.5423/PPJ.OA.10.2016.0214.

Aboukhaddour, R., Kim, Y.M., \& Strelkov, S.E. (2012). RNA-mediated gene silencing of ToxB in Pyrenophora tritici-repentis. Molecular Plant Pathology, 13(3), 318-326. DOI: 10.1111/j.1364-3703.2011.00748.x.

Aboukhaddour, R., Turkington, T.K., \& Strelkov, S.E. (2013). Race structure of Pyrenophora triciti-repentis (tan spot of wheat) in Alberta, Canada. Canadian Journal of Plant Pathology, 35(2), 256-268. DOI: 10.1080/07060661.2013.782470.

Ali, S., \& Francl, L.J. (2002). Race structure of Pyrenophora tritici-repentis isolates obtained from wheat in South America. Plant Protection Science-Prague, 38, 302-304. DOI: 10.17221/10473-PPS.

Ali, S., \& Francl, L.J. (2003). Population Race Structure of Pyrenophora tritici-repentis prevalent on wheat and noncereal grasses in the Great Plains. Plant Disease, 87(4), 418-422. DOI: 10.1094/PDIS.2003.87.4.418.

Ali, S., Gurung, S., \& Adhikari, T.B. (2010). Identification and characterization of novel isolates of Pyrenophora tritici-repentis from Arkansas. Plant Disease, 94(2), 229-235. DOI: 10.1094/PDIS-94-2-0229.

Ali, S., Ling, H., Meinhardt, S.W., \& Francl, L.J. (2002). A new race of Pyrenophora tritici-repentis that produces a putative host-selective toxin. Phytopathology, 92, S3. 
Amaike, S., Ozga, J., Basu, U., \& Strelkov, S. (2008). Quantification of ToxB gene expression and formation of appressoria by isolates of Pyrenophora tritici-repentis differing in pathogenicity. Plant Pathology, 57(4), 623-633. DOI: 10.1111/j.1365-3059.2007.01821.x.

Andrie, R.M., Pandelova, I., \& Ciuffetti, L.M. (2007). A combination of phenotypic and genotypic characterization strengthens Pyrenophora tritici-repentis race identification. Phytopathology, 97(6), 694701. DOI: 10.1094/PHYTO-97-6-0694.

Ballance, G., Lamari, L., Kowatsch, R., \& Bernier, C. (1996). Cloning, expression and occurrence of the gene encoding the Ptr necrosis toxin from Pyrenophora tritici-repentis. Molecular. Plant Pathology, 1209. DOI: 10.1007/978-94-011-5218-1_21.

Ballance, G.M., Lamari, L., \& Bernier, C.C. (1989). Purification and characterization of a host-selective necrosis toxin from Pyrenophora tritici-repentis. Physiological and Molecular Plant Pathology, 35(3), $203-213$. DOI: $10.1016 / 0885-5765(89) 90051-9$.

Bankina, B., Bimšteine, G., Arhipova, I., Kaņeps, J., \& Stanka, T. (2018). Importance of agronomic practice on the control of wheat leaf diseases. Agriculture, 8(4), 56. DOI: 10.3390/agriculture 8040056.

Benslimane, H., Lamari, L., Benbelkacem, A., Sayoud, R., \& Bouznad, Z. (2011). Distribution of races of Pyrenophora tritici-repentis in Algeria and identication of a new virulence type. Phytopathologia mediterranea, 50(2), 203-211.

Bertagnolli, V.V., Ferreira, J.R., Liu, Z., Rosa, A.C., \& Deuner, C.C. (2019). Phenotypical and genotypical characterization of Pyrenophora tritici-repentis races in Brazil. European Journal of Plant Pathology, 154(4), 995-1007. DOI: 10.1007/s10658-019-01720-3.

Ciuffetti, L., Manning, V., Pandelova, I., Faris, J., Friesen, T., Strelkov, S., . . Figueroa, M. (2014). Pyrenophora tritici-repentis: a plant pathogenic fungus with global impact. In: Dean R., Lichens-Park A., Kole C. (eds) Genomics of Plant-Associated Fungi: Monocot Pathogens (pp. 1-39). Berlin, Heidelberg: Springer. DOI: 10.1007/978-3-662-44053-7 1.

Ciuffetti, L.M., Francl, L.J., Ballance, G.M., Bockus, W.W., Lamari, L., Meinhardt, S.W., \& Rasmussen, J.B. (1998). Standardization of toxin nomenclature in the Pyrenophora tritici-repentis/wheat interaction. Canadian Journal of Plant Pathology, 20(4), 421-424. DOI: 10.1080/07060669809500415.

Ciuffetti, L.M., Manning, V.A., Pandelova, I., Betts, M.F., \& Martinez, J.P. (2010). Host-selective toxins, Ptr ToxA and Ptr ToxB, as necrotrophic effectors in the Pyrenophora tritici-repentis-wheat interaction. New Phytologist, 187(4), 911-919. DOI: 10.1111/j.1469-8137.2010.03362.x.

Diedicke, H. (1902). Uber den zusammenhang zwischen Pleospora-und Helminthosporium-arten (About the connection between Pleospora and Helminthosporium species). Centrablatt fur Bakteriologie und Parasitenkunde Jena, Abt. 9, 317-329. (in German).

Effertz, R., Meinhardt, S.W., Anderson, J., Jordahl, J., \& Francl, L. (2002). Identification of a chlorosis-inducing toxin from Pyrenophora tritici-repentis and the chromosomal location of an insensitivity locus in wheat. Phytopathology, 92(5), 527-533. DOI: 10.1094/PHYTO.2002.92.5.527.

Figueroa Betts, M., Manning, V.A., Cardwell, K.B., Pandelova, I., \& Ciuffetti, L.M. (2011). The importance of the N-terminus for activity of Ptr ToxB, a chlorosis-inducing host-selective toxin produced by Pyrenophora tritici-repentis. Physiological and Molecular Plant Pathology, 75(4), 138-145. DOI: 10.1016/j.pmpp.2011.03.002.

Gamba, F., Bassi, F., \& Finckh, M. (2017). Race structure of Pyrenophora tritici-repentis in Morocco. Phytopathologia mediterranea, 56(1), 119-126.

Gamba, F., Lamari, L., \& Brülé-Babel, A. (1998). Inheritance of race-specific necrotic and chlorotic reactions induced by Pyrenophora tritici-repentis in hexaploid wheats. Canadian Journal of Plant Pathology, 20(4), 401-407. DOI: 10.1080/07060669809500411.

Guo, J., Shi, G., \& Liu, Z. (2018). Characterizing Virulence of the Pyrenophora tritici-repentis Isolates Lacking Both ToxA and ToxB Genes. Pathogens, 7(3), 74. DOI: 10.3390/pathogens7030074.

Hosford, R.M. (1971). A form of Pyrenophora trichostoma pathogenic to wheat and other grasses. Phytopathology, 61(1), 28-32.

Hosford, R.M. (1981). Tan spot - developing knowledge 1902-1981, virulent races and wheat differentials, methodology, rating systems, other leaf diseases, literature, In: Tan Spot of Wheat and Related Diseases Workshop, July 14-15 1981 (pp. 1-25), Fargo, North Dakota, North Dakota State University.

Kamel, S., Cherif, M., Hafez, M., Despins, T., \& Aboukhaddour, R. (2019). Pyrenophora tritici-repentis in Tunisia: race structure and effector genes. Frontiers in Plant Science, 10, p. 1562. DOI: 10.3389/fpls.2019.01562.

Krupinsky, J.M. (1982). Observations on the host range of isolates of Pyrenophora trichostoma. Canadian Journal of Plant Pathology, 4(1), 42-46. 
Lamari, L., \& Bernier, C. (1989). Virulence of isolates of Pyrenophora tritici-repentis on 11 wheat cultivars and cytology of the differential host reactions. Canadian Journal of Plant Pathology, 11(3), 284-290.

Lamari, L., Bernier, C.C., \& Smith, R.B. (1991). Wheat genotypes that develop both tan necrosis and extensive chlorosis in response to isolates of Pyrenophora tritici-repentis. Plant Disease, 75(121-122).

Lamari, L., Sayoud, R., Boulif, M., \& Bernier, C. (1995). Identification of a new race in Pyrenophora triticirepentis: implications for the current pathotype classification system. Canadian Journal of Plant Pathology, 17(4), 312-318. DOI: 10.1080/07060669509500668.

Lamari, L., Strelkov, S., Yahyaoui, A., Orabi, J., \& Smith, R. (2003). The identification of two new races of Pyrenophora tritici-repentis from the host center of diversity confirms a one-to-one relationship in tan spot of wheat. Phytopathology, 93(4), 391-396. DOI: 10.1094/PHYTO.2003.93.4.391.

Lamari, L., \& Strelkov, S.E. (2010). Minireview/Minisynthèse The wheat/Pyrenophora tritici-repentis interaction: progress towards an understanding of tan spot disease. Canadian Journal of Plant Pathology, 32(1), 4-10. DOI: 10.1080/07060661003594117.

Lamari, L., Strelkov, S.E., Yahyaoui, A., Amedov, M., Saidov, M., Djunusova, M., \& Koichibayev, M. (2005). Virulence of Pyrenophora tritici-repentis in the countries of the Silk Road. Canadian Journal of Plant Pathology, 27(3), 383-388. DOI: 10.1080/07060660509507236.

Manning, V.A., Chu, A.L., Steeves, J.E., Wolpert, T.J., \& Ciuffetti, L.M. (2009). A host-selective toxin of Pyrenophora tritici-repentis, Ptr ToxA, induces photosystem changes and reactive oxygen species accumulation in sensitive wheat. Molecular Plant-Microbe Interactions, 22(6), 665-676. DOI: 10.1094/ MPMI-22-6-0665.

Manning, V.A., \& Ciuffetti, L.M. (2005). Localization of Ptr ToxA produced by Pyrenophora tritici-repentis reveals protein import into wheat mesophyll cells. The Plant Cell, 17(11), 3203-3212. DOI: 10.1105/ tpc. 105.035063 .

Manning, V.A., Hamilton, S.M., Karplus, P.A., \& Ciuffetti, L.M. (2008). The Arg-Gly-Asp-containing, solventexposed loop of Ptr ToxA is required for internalization. Molecular Plant-Microbe Interactions, 21(3), 315-325. DOI: 10.1094/MPMI-21-3-0315.

Maraite, H. (1997). Evolution of the nomenclature used for Helminthosporium spp. causing leaf blight of wheat In: International Workshop on Helminthosporium Diseases of Wheat: Spot Blotch and Tan Spot $9-14$ February 1997 (pp. 6-9), Mexico, El Batán, CIMMYT.

Martinez, J.P., Oesch, N.W., \& Ciuffetti, L.M. (2004). Characterization of the multiple-copy host-selective toxin gene, ToxB, in pathogenic and nonpathogenic isolates of Pyrenophora tritici-repentis. Molecular PlantMicrobe Interactions, 17(5), 467-474. DOI: 10.1094/MPMI.2004.17.5.467.

Mironenko, N., Kovalenko, N., \& Baranova, O. (2019). Characteristics of the geographically distant populations of Pyrenophora tritici-repentis in terms of virulence and ToxA and ToxB toxin-forming genes). Plant Protection News, 1(99), 24-29. DOI: 10.31993/2308-6459-2019-1(99)-24-29. (in Russian).

Misra, A., Pandey, S., \& Misra, A. (1979). Drechslera tritici-repentis on triticales-a new record. Indian Phytopathology, 32(4), 656-657.

Momeni, H., Aboukhaddour, R., Javan-Nikkhah, M., Razavi, M., Naghavi, M., Akhavan, A., \& Strelkov, S. (2014). Race identification of Pyrenophora tritici-repentis in Iran. Journal of plant pathology, 96(2), 287294. DOI: $10.4454 / J P P . V 96 I 2.036$.

Moreno, M.V., Stenglein, S., \& Perelló, A.E. (2015). Distribution of races and Tox genes in Pyrenophora tritici-repentis isolates from wheat in Argentina. Tropical plant pathology, 40(2), 141-146. DOI: 10.1007/ s40858-015-0011-2.

Orolaza, N., Lamari, L., \& Ballance, G. (1995). Evidence of a host-specific chlorosis toxin from Pyrenophora tritici-repentis, the causal agent of tan spot of wheat. Phytopathology, 85(10), 1282-1287.

Pandelova, I., \& Ciuffetti, L.M. (2005). A proteomics-based approach for identification of the ToxD gene. Fungal Genetics Newsletter, 52(318) (Suppl.).

Ronis, A., Semaškienè, R., Dabkevičius, Z., \& Liatukas, Ž. (2009). Influence of leaf diseases on grain yield and yield components in winter wheat. Journal of Plant Protection Research. 49(2), 151-157. DOI: 10.2478/ v10045-009-0021-5.

Sarma, G.N., Manning, V.A., Ciuffetti, L.M., \& Karplus, P.A. (2005). Structure of Ptr ToxA: An RGD-containing host-selective toxin from Pyrenophora tritici-repentis. The Plant Cell, 17(11), 3190-3202. DOI: 10.1105/ tpc.105.034918.

Shoemaker, R.A. (1962). Drechslera ito. Canadian Journal of Botany, 40(6), 809-836.

Strelkov, S., \& Lamari, L. (2003). Host-parasite interactions in tan spot [Pyrenophora tritici-repentis] of wheat. Canadian Journal of Plant Pathology, 25(4), 339-349. DOI: 10.1080/07060660309507089. 
Strelkov, S., Lamari, L., \& Ballance, G. (1998). Induced chlorophyll degradation by a chlorosis toxin from Pyrenophora tritici-repentis. Canadian Journal of Plant Pathology, 20(4), 428-435. DOI: 10.1080/07060669809500417.

Strelkov, S.E., Kowatsch, R.F., Ballance, G.M., \& Lamari, L. (2006). Characterization of the ToxB gene from North African and Canadian isolates of Pyrenophora tritici-repentis. Physiological and Molecular Plant Pathology, 67(3-5), 164-170. DOI: 10.1016/j.pmpp.2005.12.004

Strelkov, S.E., Lamari, L., \& Ballance, G.M. (1999). Characterization of a host-specific protein toxin (Ptr ToxB) from Pyrenophora tritici-repentis. Molecular Plant-Microbe Interactions, 12(8), 728-732. DOI: 10.1094/ MPMI.1999.12.8.728.

Strelkov, S.E., Lamari, L., Sayoud, R., \& Smith, R.B. (2002). Comparative virulence of chlorosis-inducing races of Pyrenophora tritici-repentis. Canadian Journal of Plant Pathology, 24(1), 29-35. DOI: 10.1080/07060660109506967.

Švarta, A., Bimšteine, G., Gaile, Z., Stanka, T., Daugaviņa, L., \& Plūduma-Pauniņa, I. (2020). Development of winter wheat blotches depending on fungicide treatment schemes and nitrogen rates. Research for Rural Development, 35, pp. 7-13. DOI: 10.22616/rrd.26.2020.001.

Tomas, A., \& Bockus, W. (1987). Cultivar-specific toxicity of culture filtrates of Pyrenophora tritici-repentis. Phytopathology, 77(9), 1337-1340.

Tomas, A., Feng, G., Reeck, G., Bockus, W., \& Leach, J. (1990). Purification of a cultivar-specific toxin from Pyrenophora tritici-repentis, causal agent of tan spot of wheat. Molecular Plant-Microbe Interactions, 3(4), 221-224.

Tuori, R., Wolpert, T., \& Ciuffetti, L. (1995). Purification and immunological characterization of toxic components from cultures of Pyrenophora tritici-repentis. Molecular Plant-Microbe Interactions, 9(43), 41-48.

Wijayawardene, N.N., Crous, P.W., Kirk, P.M., Hawksworth, D.L., Boonmee, S., Braun, U., . . . Hyde, K.D. (2014). Naming and outline of Dothideomycetes-2014 including proposals for the protection or suppression of generic names. Fungal Diversity, 69(1), 1-55. DOI: 10.1007/s13225-014-0309-2.

Молдажанова, Р.А., Мауленбай, А.Д., \& Рсалиев, А.С. (2020). Расовый состав возбудителя Pyrenophora tritici-repentis в южных регионах Казахстана в 2018 год. (Racial composition of the pathogen Pyrenophora tritici-repentis in the southern regions of Kazakhstan in 2018). Вестник КазНУ. Серия биологическая, 84(3), 98-106. (in Russian). 